\title{
The Transparency Frontier in Brazilian Foreign Policy
}

\author{
Laura Trajber Waisbich* \\ Raísa Cetra** \\ Joara Marchezini***
}

\begin{abstract}
In 2011, Brazil finally approved a Freedom of Information (FOI) Act that recognises and regulates the right to public information. However, scholars have paid insufficient attention to its impact on Brazilian foreign policy. How has the Brazilian ministry of foreign affairs responded and adapted to this new law? Has it been adequately implemented, and if not, in what ways? Also, how do these challenges in promoting transparent foreign policy connect to the broader debate about democratising Brazilian foreign policy? This article analyses the implementation of the FOI Act by mapping all the requests for information refused by the foreign affairs ministry since 2012, and exploring its legal and political justifications for withholding information. We further argue that the ministry's adherence to the law is an important factor in the democratisation of foreign policymaking in Brazil.
\end{abstract}

Keywords: Brazilian Foreign Policy; Transparency; Public Policy; Freedom of Information; Democratisation.

\section{Introduction}

In recent years, the democratisation of Brazilian foreign policy has become an important subject in the field of foreign policy analysis (Lima 2000; Pinheiro 2003; Lopes 2012; Lopes 2014a; Milani and Pinheiro 2013, Ramanzini Júnior and Farias 2014, Farias and Ramanzini Júnior 2015). In addition, social actors ranging from members of the business community to social movements (GRRI 2014a; Nader and Waisbich 2014; Barbosa 2014b; Cervo and Lessa 2014) have called on the main public bodies responsible for foreign policy - particularly the ministry of foreign affairs, also known as Itamaraty, ${ }^{1}$ and the Presidency ${ }^{2}$ - to open up to social dialogue and public participation in the decisionmaking process.

* Brazilian Centre for Analysis and Planning (CEBRAP), and South-South Cooperation Research and Policy Center (Articulação SUL), São Paulo-SP, Brazil; laura.waisbich@gmail.com.

** National University of Lanús, and Centro de Estudios Legales y Sociales (CELS), Buenos Aires, Argentina; rscetra@gmail.com.

*** Article 19 Brazil, São Paulo-SP, Brazil; joara@article19.org. 
Expanding participation requires public bodies to become more transparent. This commitment is particularly important in the foreign policy realm, since foreign policy has traditionally been shielded from public scrutiny and insulated from other government bodies, including other ministries. Since 2011, however, calls for greater transparency in Brazilian foreign policy have been bolstered by the Freedom of Information Act (Act 12.527/2011, hereafter the FOI Act) (Brazil 2011a). Analysing how those public bodies responsible for foreign policy adhere to this law will therefore make a significant contribution to the foreign policy democratisation debate. We also argue that the FOI Act is itself a key variable for understanding the opening up of Itamaraty.

Literature presents this democratisation process as largely having resulted from mounting domestic pressure, particularly after the end of the authoritarian regime in the late $1980 \mathrm{~s},{ }^{3}$ for access to an increasingly competitive and distributive foreign policy (Lima 2000; Spektor 2012; Casarões 2014). Equally relevant are Itamaraty's internal reformist dynamics (Lopes 2014a), and the start of the first Workers' Party presidency in 2003. These elements brought a new constellation of social actors into the foreign policy process. The opening up of foreign policy was also influenced by external factors, notably the dynamics of an increasingly interdependent world. Another element that played a role was the global impetus towards open government. This was crystallised in 2011 in the Open Government Partnership (OGP), of which Brazil is a founding member. Several of the first commitments Brazil made under the OGP framework (Brazil 2011b; Brazil 2013) were related to the implementation of the FOI Act.

In order to describe this phenomenon more closely, França and Sanchez (2009) refer to a dual process of the horizontalisation and verticalisation of Brazilian foreign policy. Horizontalisation denotes an increase in the number of government actors and administrative units involved in the decision-making process. By contrast, verticalisation implies a higher level of participation by a larger number of non-government actors, including academia, the private sector, political parties, and organised civil society.

Albeit transformative, scholars do not see this progressive opening up of Brazilian foreign policy as breaking away from its traditional bureaucratic insulation. Instead, they believe these changes show how Itamaraty has partially lost its 'policy-making monopoly', and now not only needs to negotiate with new and larger domestic coalitions, but also perform new policy co-ordination roles (França and Sanchez 2009; De Faria 2012; Pinheiro and Milani 2011).

Another issue addressed in the democratisation debate has been whether or not to conceive of Brazilian foreign policy as public policy. For Milani and Pinheiro (2013), this entails bringing it into the realm of politics, whereas state and governmental choices at the international level result from disputes, bargaining, and agreements among different actors. Similarly, Sanchez et al (2006) talk about decision-making processes that are structured like polyarchies, forming a continuum from the national to the international.

Democratisation therefore results in a greater politicisation ${ }^{4}$ of Brazilian foreign policy (Lima 2003; Milani and Pinheiro 2013). Even if, for decades, Brazilian foreign policy was already subjected to disputes both inside and outside the ministry (Hirst and Pinheiro 1995), current levels of politicisation are considerably higher. This is illustrated, for 
example, by the greater prominence of foreign policy issues in election debates (Lopes and De Faria 2014) and within the legislative branch (Lima 2003; Lima and Santos 2011, Sanchez et al 2006). Consequently, 'national interest' enters the discussion (Lopes 2012), and demands for democratising the foreign policy process becomes a call for the ability to participate in, influence, and challenge the construction of Brazilian 'national interest'.

In Brazil, public policies are subjected to social pressures to respond to the imperatives of transparency, accountability, and citizen participation (Avritzer 2002; Sanchez et al 2006; Nader and Waisbich 2014). Securing this legitimacy in a highly diverse democratic state has been part of the rhetoric of high-level representatives of Itamaraty since at least the Fernando Henrique Cardoso era (1995-2002). More recently, in 2014, former Foreign Minister Luiz Alberto Figueiredo Machado stated that 'a foreign policy that ignores the aspirations of society becomes deficient in support and backing' (MRE 2014).

However, there is still a disconnect between discourse and action. The Foreign Policy White Paper promised in 2014 was never published. Similarly, nothing has come of a series of debates in 2013 about the establishment of permanent and institutional mechanisms of dialogue between the ministry and civil society. ${ }^{5}$ Participation, therefore, is still ad hoc, and the opening up to society is controlled and selective, as illustrated by Lopes (2014a) in his narrative about the 'mitigated republicanism' of Brazilian foreign policy.

Furthermore, in a recent work, Farias and Ramanzini Júnior (2015) call for methodological caution about the concrete impacts of the democratisation of Brazilian foreign policy. They are skeptical about considering a dual analysis of insulation versus horizontalisation, raising several methodological issues which they believe should be addressed in order to assess whether increased participation has actually changed policy outcomes, rather than just expanding the number of participants in the policy process.

In support of this call to evaluate the concrete outcomes of the so-called democratisation wave, we turn to the issue of transparency and accountability in Brazilian foreign policy - specifically, the implementation of the FOI Act by Itamaraty.

The FOI Act and its Regulatory Decree (7,724/2012) (Brazil 2012) represent a major breakthrough. They regulate the right to access public information in Brazil, already guaranteed by Articles 5, 37 and 216 of the 1988 Federal Constitution. The FOI Act is aimed at 'guaranteeing disclosure as a rule and secrecy as an exception' in public administration (Article 3). It has resulted from more than 20 years of activism, which gained new political impetus in the 2000s when the Inter-American Court of Human Rights decision against Brazil in the case of Gomes Lund et al (TSE 2013) required that Brazil adopt such a law.

In this new legal framework, the right of citizens to information means both the right to receive information (through proactive state transparency) and to request information (through passive state transparency), an idea closely related to the concept of citizen oversight. Furthermore, public bodies have a general duty to provide the public with information about their activities, programmes, and public spending (proactive transparency). Hence, the right of access to information not only has great potential to strengthen the transparency of institutions of representative government, but is also an important tool 
for empowering citizens, by allowing them to participate more actively and effectively in public decision-making processes (IACHR 2012).

Both the act and the decree focus on strengthening the capacity of public bodies to provide information. One of the landmarks they have established is the principle of the supremacy of public interest and a presumption of openness, calling for 'the least restrictive criteria possible' in the process of deciding whether or not to disclose information (Decree Article 7).

According to legal experts, any restriction of this right must itself be based on the public interest (Mendel 2009), and public authorities must again weigh the public interest in considering whether or not to withhold information on the grounds that this would harm the public interest. In others words, 'it must be demonstrated that the harm to the objective is greater than the public's interest in having the information' (IACHR 2012: 17), referred to as 'harm and public interest tests' (Mendel 2009). Also, states have a duty to justify their refusals to release information, providing, in written responses, (IACHR 2012; IAHRC 2007) a 'sufficient explanation of the legal standards and the reasons supporting such decision, demonstrating that the decision was not discretionary or arbitrary' (IACHR 2012: 18).

The FOI Act is particularly relevant to the debate about the democratisation of Brazilian foreign policy. Given the clear link between the Act on the one hand and deepening democracy in terms of citizen oversight, participation, and the primacy of the public interest in public administration on the other, the evolution of Itamaraty's implementation of the Act is an important aspect which should be closely monitored by those interested in the formation of foreign policy in democratic states. ${ }^{6}$ In a comparative study, Toby Mendel (2009) has noted that exceptions to the openness rule in respect of international relations and national security are common in FOI laws around the world, and are seen as major challenges in guaranteeing the right to information.

The Brazilian FOI Act imposes clear limits on the right to information about foreign affairs. Notably, Article 23 of the Act and Article 25 of the Decree stipulate that information 'considered vital to the security of society or the State' can be classified when, to cite the instances related to foreign relations, its release would endanger or damage a) the defence, national sovereignty, or integrity of the national territory; b) the process of conducting negotiations or international relations; or c) involve classified information provided by other states and international bodies. Additionally, information related to international matters may be classified when it could endanger the security of the president or vicepresident (FOI Act Article $24 \$ 2$ ), is subject to secrecy clauses in international treaties and agreements (Article 36), or involves personal information (Article 31).

Given all this, we need to ask: how has the foreign affairs ministry responded and adapted to this new law? What problems have arisen around its implementation, and how do they connect to the broader debate about democratising Brazilian foreign policy?

In response, this article examines all the requests for information denied by the ministry during the first three years of the FOI Act. The choice to focus on this particular public authority responds, firstly, to the fact that information about foreign relations is potentially subject to classification under Article 23 of the FOI Act and Article 25 of the 
Decree, and that these relatively broad secrecy provisions (such as 'the defence, national sovereignty, or integrity of the national territory' or 'the process of conducting negotiations or international relations') cover a large part the work of the ministry of foreign affairs - larger than those of other ministries. Secondly, the problems surrounding the implementation of the FOI Act are not only normative in nature. They also involve aspects of political culture as well as the bureaucratic culture within Itamaraty that contribute to the tensions surrounding the process of democratising Brazilian foreign policy.

In what follows, we will set out the method used for this study well as the main findings, and suggest how the FOI Act could be used to improve the ministry's transparency.

\section{Method}

We use the implementation of the FOI Act and its decree as one variable in the phenomenon known as the democratisation of Brazilian foreign policy. To this end, we examine, using a term coined by Andrew Bennett (2002), 'a well-defined aspect' of the implementation of the Act during its first three years, namely all the requests for information denied - either wholly or partially - by the ministry.

Denials are the operationalisation of exemptions under the Act. The authority in question is also obliged to state why, and on what basis, it has decided not to disclose information, including considerations of the public interest. Therefore, analysing the denials in this instance allows us to build a profile of Itamaraty's interpretation of the FOI Act.

This study has three specific objectives. The first is to study the ministry's implementation of the Act, and identify disparities between its requirements and the ministry's responses. The second is to link the findings about access to information about foreign policy-related issues to the broader discussion about the democratisation of Brazilian foreign policy. The third is to point to some areas where the Act may help to open up Brazilian foreign policy. In the process, we seek to contribute to the literature about how the drive to greater transparency in Brazilian governance is contributing to the democratisation of foreign policy. More research is needed in the future, looking for stronger causal linkages and bolder theoretical contributions.

We use quantitative and qualitative methods to examine two hypotheses. The first is that the ministry is interpreting key concepts in the FOI Act, such as 'public interest' and 'the security of the state and society', in a restrictive way. The second is that bureaucratic practices non exclusive to the ministry are also contributing to poor implementation of the Act. These hypotheses will be tested by analysing the arguments the ministry uses most frequently for classifying information, as well as its responses to requests for information in general. Its responses are assessed against the human rights-based approach to access to information that underpins the principle of the 'primacy of the public interest' (the 'public interest test'), and the duty of the state to justify any decision to deny access to public information.

In concrete terms, we have built a database of requests for information denied by Itamaraty, either wholly or partially, between May 2012 and May 2015, the first three years of the law's currency. It comprises 567 requests for information, of which 475 were 'wholly 
denied', and 92 were 'partially denied. The authors obtained copies of these requests by filing two requests for information under the FOI Act. For the same period, official statistics provided by the former Office of the Federal Comptroller General (CGU) ${ }^{7}$ record 573 requests for information from the ministry, of which 483 were denied and 90 partially denied. The slight difference between those figures and ours result from the ministry's decision to withhold copies of requests which were still subject to appeal, or those containing personal information. The differences between the two sets of figures are reflected in Table 1.

Table 1: Wholly and partially denied requests for information submitted to the ministry of foreign affairs, May 2012 - May 2015

\begin{tabular}{lcc}
\hline Requests & CGU data & Own database \\
\hline Wholly denied & 483 & 475 \\
\hline Partially denied & 90 & 92 \\
\hline Total & 573 & 567 \\
\hline
\end{tabular}

Source: Compiled by the authors.

Among other things, these figures point to the fact that the ministry granted most requests for information in the period in question. According to the CGU, the ministry received 1818 requests for information, and the denials amount to 32 per cent of this total. More information is given in Table 2.

Table 2: Requests for information submitted to the ministry of foreign affairs by year, May 2012 May 2015

\begin{tabular}{lcccc}
\hline Year & Requests & Full releases & Partially denied & Wholly denied \\
\hline May 2012 to May 2013 & 605 & 482 & 29 & 65 \\
\hline June 2013 to May 2014 & 789 & 325 & 38 & 390 \\
\hline June 2014 to May 2015 & 425 & 298 & 23 & 28 \\
\hline
\end{tabular}

Source: Compiled by the authors, drawing on CGU data.

The CGU also has other categories for assessing the responses of public authorities to requests for information, including 'repeated question', or 'information does not exist'. This explains why the total requests exceeds the sum of the remaining columns.

Wholly denied requests for information peaked in 2013. In that year, requests included 247 quasi-identical demands for information about the living costs of and remuneration of local employees at Brazilian missions around the world. These probably came from the same applicant. We decided to keep those requests in the database even though they may cause a statistical bias.

We also conducted a more qualitative analysis of requests by two civil society organisations working in the field of human rights: Conectas Human Rights, and Article 19 Brazil. $^{8}$ In the period under review, Conectas filed seven requests for information, while 
Article 19 filed five. ${ }^{9}$ These requests are included in the database, except for one request from Conectas that was still open at the time of the analysis.

These organisations operate like 'normative entrepreneurs' (Finnemore and Sikkink 1998), using the FOI Act as an instrument of political advocacy vis-à-vis the ministry. Analysing the exchanges between a state body and these groups is a relevant exercise, firstly because access to public information is a constitutional right, and secondly because, in terms of Article 4 of the Federal Constitution, human rights are meant to be a guiding principle of Brazilian international relations. Finally, analysing requests for information filed by CSOs to complement those of ordinary citizens allows us to reveal some of the additional tensions surrounding the FOI Act in relation to Brazilian foreign policy, since the relationship between organised civil society and Itamaraty is widely perceived to be a politically challenging one (Milani 2011).

\section{Itamaraty's practice of denying access to information}

\section{Denials based on the secrecy exemptions in the FOI Act}

This section is not aimed at questioning Itamaraty's authority to classify information as sensitive, but rather to gain greater clarity about the conflicts between Itamaraty and the parties requesting the information. The issues raised by these parties about the legitimacy of Itamaraty's decisions are not only the normal types of challenges one should expect when a new regulation is implemented; they are also symptoms of the broader negotiations about Brazilian foreign policy.

Only 82 requests information submitted to the ministry were explicitly denied in terms of the secrecy exemptions in the FOI Act or Decree, constituting less than $15 \%$ of all requests that were partially or wholly denied. Of those, 31 were requests for information about foreign policy issues, including international co-operation (agreements or reports), diplomacy (official correspondence or documents relating to official visits), international organisations (reports about Brazil or Brazilian participation), the Brazilian position on specific thematic issues as well as bilateral relations, and access to theses of Itamaraty's diplomatic school (Instituto Rio Branco). The remaining 51 requests were mostly related to aspects of public administration, notably Itamaraty's public spending.

Considering only the requests for information about foreign policy issues, thus excluding those on public spending, 11 requests were denied on the basis of Article 23 of the FOI Act and Article 25 of the Decree (among them three requests filed by Conectas), three because they involved a specific international agreement; two because they involved personal information; and three because they were subject to secrecy clauses in other legislation (such as the Bank Secrecy Act). Itamaraty denied the remaining 12 requests without stating the exact grounds in terms of the FOI Act, or the classification of the item in question.

The number of denials involving classified information was also considerably smaller than the number of denials based on Article 13 (which exempts public agencies from providing information when they would need to process data (see section on the issue of 
additional data processing below). Nevertheless, they are central to the present discussion about the democratisation of foreign policy precisely because they deal with the core issue of 'substantive' denials, namely those which require Itamaraty to provide the applicant with the reasons classifying the information in question, thus engaging with the substantive (and political) aspect of the public interest exercise. By contrast, denials based on Article 13 are 'procedural' denials involving information management challenges, thus engaging with the public interest test mostly from a public management perspective.

\section{State security and the public interest}

Exchanges between the ministry and applicants reveal three main areas of conflict over the Ministry's interpretation of the Act, notably Article 23. These exchanges illustrate the inherent tension between notions of state security and the public interest, since - in three years of implementation - no balance had been struck between these conflicting principles, possibly due to the lack of jurisprudence on the matter.

The first point of contention was the ministry's failure to explain and justify its classification of information. This was most evident in cases where Itamaraty did not provide any reasons for denying requests for information, as the Act obliges it to do, or merely cited the article (or the specific legislation) that allowed the information to be classified without specifying the degree of secrecy, the classification authority, the legally established hypotheses or motivation, and the classification number, as required by the Act. It only mentioned these requirements, or sought to justify the classification, when applicants contested its decisions, which only happened in $37 \%$ of 82 analysed cases.

Second, tensions also appeared around the reasons provided for classification. In some cases, the ministry resorted to polemic reasoning to sustain its refusals, and in others, its reasons were legally inconsistent. By the end of the period under review, the ministry did not appear to have developed consistent interpretations of the security of the state or society, or the public interest. Moreover, its responses changed in the course of appeals processes, and bore little relation to the formal requirements for justifying the classification of information.

One clear example is a request filed by Conectas for information about the IBSA Poverty Alleviation Fund (a trilateral fund established by India, Brazil and South Africa), namely copies of financial and impact reports about funded projects. The ministry's first denial was based on the need for 'additional data processing' (Article 13). Upon appeal, it changed its response to a secrecy-based argument, stating that the requested information was classified under an international agreement. In response to a second appeal, it finally stated that the reports in question were not in the ministry's possession, and were held by the United Nations Development Programme (Conectas 2015c, Herdy 2014).

Third, tensions also arose around the way in which Itamaraty motivated its use of the 'national interest' provision in the FOI Act. In one example, the ministry denied a request by Conectas to release Brazilian diplomatic cables providing voting instructions on a resolution about Iran tabled in the UN Human Rights Council in 2015. When asked to provide the reasons for its refusal, it stated: 
The possibility of classifying information as secret does not depend, therefore, on establishing the actual existence of a threat to the security of society or the State, but on the calculation that aims to determine whether the release of information $\mathrm{x}$ or $\mathrm{y}$ will have a negative impact on the country's negotiations and international relations, by means of which this Ministry actively seeks to defend the interests and principles of the Brazilian State and society (Conectas 2015b).

Therefore, the ministry's use of the 'national interest' to deny access to information seemed to collide with applicants' perceptions of the public interest, as well as their view that the 'public interest test' should have prevailed. Given that the 'national interest' is a subject of dispute and social bargaining, the FOI Act inevitably becomes a frontier for clashes between social actors and state agencies in charge of foreign relations. Furthermore, the HRC Iran Vote appeals process shows how little effort is made by the ministry to link 'harmful disclosure' to the public interest imperative. According to Itamaraty, these are 'open legal concepts lacking precision that permit their identification a priori. Only in light of specific cases can the classification authority, using its discretion, assess the degree of risk or harm, whose potentiality is evidenced by the verb "could" contained in item II of article 23' (Conectas 2015b).

Protecting Brazil's negotiating position was also given as a reason for refusing to release diplomatic cables about the reform of the Inter-American Human Rights System, the object of a previous and unsuccessful request by Conectas. In both this instance and that of the HRC Iran Vote, Itamaraty defined 'state security' in a way that external actors regarded as akin to institutional or corporate security (Conectas 2015a; Conectas 2015b). In doing so, Itamaraty confirmed, within the scope of the FOI Act, a trend already identified by a series of scholars, namely that the body does not adhere sufficiently to the imperatives of public administration in a democracy (De Faria 2012; Araújo and Ventura 2014; Lopes 2014b).

Another issue is the ministry's use of the term 'disclosure requiring partner's consent' without proper legal justification, cited as a reason to deny the IBSA Fund request and 10 more of 26 requests for information about international co-operation projects implemented with public funds. ${ }^{10}$ In the case of the IBSA Fund request, the GCU - which, until early 2016, handled appeals against FOI Act decisions - eventually ruled that this contravened the FOI Act. It said secrecy should be evaluated on a case-by-case basis, and could only be invoked when the international agreement in question contained a confidentiality clause. In the absence of such a clause, the FOI Act should apply (Conectas 2015c). ${ }^{11}$

Finally, the culture of secrecy in the realm of diplomacy is still visible in the ministry's responses. For instance, in another response to the HRC Iran Vote request, it stated that:

[...] many countries that recognize, defend and promote the right to information have incorporated the element relating to international relations into their domestic laws. The United States Freedom of Information Act, for example, makes reference to 'the foreign policy' 
of the United States, and in France, the transparency law mentions French foreign policy as a possible exception to the right of access to information (Conectas 2015b).

Here, the ministry implies that foreign policy activities as a whole, both in Brazil and in other parts of the world, are somehow immune from the duty of disclosure. This rhetoric not only reveals an understanding that contradicts the FOI Act, which clearly states under what circumstances information about Brazilian foreign relations may be classified, but also Itamaraty's practice of responding positively to the majority of FOI Act requests since 2012 (CGU 2015a). This again points to the disconnect between the debate about Brazilian foreign policy as public policy, and how public officials understand - and describe - the nature of their activities.

\section{Sensitive information}

In the period under review, Itamaraty also rarely used internationally recognised procedures for redacting sensitive information, thereby enabling access to other parts of the same document. This could have been done in the case of the requests for theses from the Advanced Studies Course at the Rio Branco Institute, which diplomats attend at various points in the course of their careers. Between 2012 and 2015, Itamaraty received seven requests for theses written by diplomats, which the ministry denied on the grounds that they contained classified information or personal information, or analysed secret documents. In the first two instances, it did not opt for redacting sensitive information, which would have enabled it to release the rest of the content, in accordance with the spirit of the FOI Act.

\section{The issue of additional data processing}

In order to promote a 'culture of transparency', and strengthen public administration, the FOI Act requires the systematisation, consolidation and digitisation of information that was previously fragmented and inaccessible to the public into accessible formats. Nonetheless, Article 13 of the Decree states that a government agency can deny a request for information when it is (i) generic; (ii) disproportionate or unreasonable; or (iii) requires additional data processing and consolidation. Since these are broad provisions that provide government bodies with considerable scope for discretionary decisions, the CGU has sought to refine these definitions and guide federal agencies on how to apply them (CGU 2015b). In Itamaraty's case, improving collective understanding around Article 13 of the FOI Act is vital.

According to the CGU (2015a), in the period under review, the ministry used Article 13 as a justification for $88 \%$ of denials. Of these, it said $74.74 \%$ required additional data processing; $9.52 \%$ were generic; and $3.93 \%$ were disproportionate or unreasonable. The requests for information could indeed have been deficient in this way. However, it could 
also mean that the ministry does not really want to make an effort to convert information in its possession into public information.

In an attempt to clarify this, the authors returned to the original sample and found 420 instances where applications were denied on the grounds that this would require 'additional work', including 'additional data processing' (Decree, Article 13, III). These included instances where requests were denied on procedural and well as substantive grounds (Article 13, I and II). In one example, a request was denied on the grounds that the documentation would be 'disproportionate', but upon closer examination it becomes clear that it could have been granted if Itamaraty had decided to scan or digitize existing information.

Four factors are key to understanding these denials. First, as in the cases of allegedly classified information, each denial based on Article 13 ought to be justified on a case-bycase basis, aimed at safeguarding the public interest. However, in the case of the vast majority of the 420 requests said to require 'additional work', the ministry said it would 'need to produce or consolidate information'. Going forward, the ministry should reconsider these grounds for refusals, especially where existing information needs to be systematised, since this is required by the FOI Act, and is a clear instance where the Act could serve as a tool for improving public management.

For instance, in the period under review several denied requests related to information about visas granted to foreign nationals, or diplomatic visas, ${ }^{12}$ which Brazilian consulates could be expected to systematise. The fact that this is not being done, and the information is therefore not publicly available, points to a gap in transparency. In this instance, the ministry could and should use the FOI Act as an opportunity to produce new data and collate existing information, because requests under the Act are indicators of what Brazilian citizens want to know, and this type of data is relevant to the policy cycle: planning, implementation, monitoring, and evaluation.

In addition, in $83 \%$ of the 420 'additional work' cases, the ministry said the requests would entail the reassignment of staff, or that information was not available in digital format. Taking into account international standards on the right to information, the authors regard these responses as inadequate as they do not explain to the applicants how much it would cost to produce the requested information. One request asked the government to list gifts to foreign officials in the period January 1995 to April 2013. In response, Itamaraty stated that 'processing the request would require deviating employees from their normal duties, which would compromise the performance of [the Ministry's] regular activities'.

Even in cases where a request might sound disproportionate, there is no reason why the ministry should not state (or be obliged to state) how many employees would need to be diverted, for how long, what loss would result from this diversion, and why the loss would be greater than the public interest gain from consolidating this information. Without this sort of information, it is impossible to state with any accuracy what 'additional data processing' could consist of, thus detracting from the efficacy of the Act in promoting transparent governance. 
Second, there were cases where the ministry declined to provide copies of existing documents on the grounds that this would take 'additional work. In response to six requests for access to documents, the ministry referred to a decision by the FOI Act appeals body, the Mixed Commission for Information Reassessment (CMRI) in which it upheld a denial, saying that 'one cannot confuse requesting data to produce information with requesting the item recording such data: the document' (CMRI 2013). For instance, one applicant asked for copies of diplomatic cables between the Brazilian embassy in Havana and the ministry during three months in 2013 about the entry of Cuban medical doctors under the More Doctors Programme. The ministry denied the request on the grounds that it was generic, and not a request for information but for specific documents. The first reason can be challenged on the grounds that the application involved a precise subject, recipient, and time frame. Second, dismissing requests because they involve specific documents seem to contradict the very notion of the right of access to information.

Third, in some cases, the ministry's Citizen Information Service (SIC) has advised applicants to approach specific sections within the ministry directly for information. However, according to the Decree (Article 9), the SIC should itself liaise with the section in question, and then provide the applicant with the required information.

One applicant asked the ministry to supply the guest list of the Brazilian embassy in Rome for the previous four years. The ministry responded by saying this type of information was not available in Brasilia, noting that 'each diplomatic representation overseas is in charge of this type of data'. However, overseas diplomatic missions are an integral part of the ministry, and the SIC should provide the relevant information.

Likewise, in the case of the request for information about the IBSA Fund referred to earlier, Itamaraty finally said the required information was in the possession of the Fund's managing board, and advised the applicant to contact the UNDP directly. However, in the course of the subsequent appeals process, Itamaraty confirmed that members of Brazil's diplomatic mission in New York served on the Fund's board (along with representatives of the UNDP and the other IBSA countries). Given this, requiring a citizen to approach an international organisation for the relevant information is clearly at odds with the spirit of the FOI Act.

Fourth, it is important to analyse another indicator of Itamaraty's willingness to generate public information: the availability of financial and human resources for producing and systematising information. How much of the ministry's budget is currently allocated to activities related to access to information was the subject of two requests for information by Article 19. It asked the ministry what the planned and actual budget had been for implementing the FOI Act in 2013 and 2014. The MRE replied that this was covered by its regular budget, and that no additional funds had been spent on human resources, equipment or facilities. According to a recent report by Article 19 (2015), this situation is not unique to Itamaraty. However, other ministries (such as health and tourism) have provided details about steps taken to implement the FOI Act, despite not having a specific budget for doing so. Article 19 could not obtain this level of information from Itamaraty.

The lack of a specific budget for implementing the FOI Act suggests that the ministry and other agencies are not regarding the Act and transparent governance as enough of a 
priority. Given the recent reductions in the ministry's budget (Mello 2015), there is cause for concern about its ability to respond to future requests for information.

A lack of human and financial resources can - and does - have a concrete impact. In 17 cases in our database, the ministry advised applicants to obtain the information in person, in Brasilia and even in New York. Further work is required to assess the circumstances under which this kind of response this could be regarded as reasonable. Clearer guidelines could prevent a situation from developing in which the ministry not only fails to digitise and produce public information, but applicants who do not have the financial capacity (to travel or to pay for documents) are disadvantaged.

Altogether, the factors discussed above strongly indicate that the ministry is not sufficiently willing or able to become more transparent, something that should be closely monitored by the oversight bodies established under the FOI Act. The lack of dedicated funding for implementing the Act is particularly relevant, since funding allocations reflects a political willingness, as is the lack of consistent criteria for rejecting applications in terms of Article 13. These represent key problems in the way of genuine institutional openness, and therefore of democratic consolidation.

\section{The democratisation of Brazilian foreign policy}

\section{The role of informal relations}

After identifying areas of tension in the implementation of the FOI Act and their linkages with the recent debates on conceiving foreign policy as a public policy, we now need to examine the extent to which FOI Act has contributed to the democratisation of foreign policy, beyond its formal application.

Traditional formalism forms a recognised part of Brazilian diplomatic culture as well as the ministry, both in a sociological and institutional sense (Ramos 1966). Our study points to traces of informality (non-compliance with formal requirements and obligations) in Itamaraty's relationship with the FOI Act. However, while this might not be explicit or intentional, this informality may inadvertently contribute to democratising Brazilian foreign policy in the longer term, and could relate to other dimensions of the social demands for openness beyond transparency per se.

One such instance is Itamaraty's use of alternative mechanisms and methods for responding to applicants, without formally granting the request in question. One example is a request by Conectas in 2013 for access to cables between the Brazilian Mission to the Organization of American States and the ministry in Brasilia during the process of reforming the Inter-American Human Rights System. Conectas said it wanted to know more about the position of the Brazilian government in this international process. While denying access to the cables, the ministry offered to stage an in-person dialogue with Conectas and other interested civil society organisations (CSOs) in order to make its positions on the reform process known (Conectas 2015a). Similarly, the ministry denied the request for access to a document about the HRC Iran Vote referred to earlier on the grounds that the 
votes had already been explained in meetings with CSOs, and during public hearings in the National Congress. In this instance, Itamaraty stated: 'It is worth pointing out that the Foreign Minister was summoned to give an explanation for this vote by Brazil at a public hearing in the Federal Senate on May 28, 2015. The mobilization by the requesting CSO was one of the reasons why this hearing occurred' (Conectas 2015b).

These exchanges show how the FOI Act could serve a purpose beyond the scope of passive transparency alone, and affect other facets of the democratisation of Brazilian foreign policy, such as encouraging proactive transparency and social participation. One unexpected consequence of these disputes is the creation of invited spaces for participation, to use John Gaventa's concept for spaces for citizen engagement in policy processes (Cornwall 2002; Gaventa 2006).

However, informality can also be a form of resistance to obligations under the FOI Act. Despite the relevance of improving dialogue with society about a given issue, these exchanges do not exempt the ministry from the obligation to respond to requests under the FOI Act, in line with the principle of maximum disclosure. Moreover, descriptions of Brazil's position on a given issue by ministry officials is not the same as having access to the original documents in which this position is expressed or decided.

On this point, it is also worth noting that access to information is a prerequisite for social participation. As Mendel has argued, it is difficult, for example, 'to provide useful input to a policy process without access to the thinking on policy directions within government' (Mendel 2009: 4). As such, access to information and mechanisms of social participation are non-competing elements of democratising Brazilian foreign policy. These two types of demands cannot be conflated, and both are regarded as fundamental by those struggling to democratise Brazilian foreign policy.

\section{Monitoring and oversight}

Monitoring and oversight of the responses to FOI requests by government agencies and the training of public officials on the FOI Act are key to making it more effective (Mendel 2009). The most efficient institutional models for applying these control functions will not be analysed in this article, but the literature on the right to access information supports the idea that 'the [monitoring/oversight] body shall be adequately protected against political interference' (Mendel 2009). In other words, it should be politically independent. In the period under review, appeals against decisions under the FOI Act were handled by the CGU and the CMRI. ${ }^{13}$ However, the autonomy of the CMRI is questionable, given that its only members are representatives of line ministries who therefore have a direct interest in its decisions and the precedents they provide. The CGU (which was formally abolished in the course of ministerial reforms introduced in May 2016) functioned as an internal oversight body over government, closely linked to the President's Office. It had the joint functions of promoting the FOI Act, and adjudicating appeals.

There are at least two other reasons why Itamaraty deserves the attention of oversight bodies. The first is because many of its activities are eligible for classification. The second 
is that it had already employed procedures for classifying information before the FOI Act came into effect (enabled by laws such as Act 11.111/2005 and Act 8.159/1991, which are less protective of civil liberties). For these reasons, it seems important to analyse how the control bodies responded to appeals against ministry denials, and whether these responses or outcomes improved the ministry's compliance with the FOI Act.

The IBSA Fund case provides a good example. While the CGU Ombudsman dismissed the third appeal, this decision was accompanied by a 15-page technical brief which fully supported granting access to this request, seeking access to information about the contribution of Brazilian public funds (and therefore taxpayers' money) to a multilateral fund. Following a fourth appeal, the CMRI upheld the denial of information, based on the arguments of the Ombudsman, and did so in a brief finding with little justification. This is a clear example of an instance where, if the requested information was not consolidated, or held by the ministry, it could have allocated the resources needed to produce it or obtain it. It was also reasonable to expect the CGU and the CMRI to compel the ministry to do so, but this did not happen.

This example reveals some of the limits of the current legal framework, notably the lack of a truly independent body to monitor and oversee its application. While it did valuable work, the former CGU depended on a gradually diminishing budget. The low rates of pro-applicant decisions by the CGU (3.12\%), and the CMRI (0\%) in respect of filings with the foreign affairs ministry (CGU 2015a) is another indicator of this challenge.

As for their educational and pedagogic roles, the new oversight bodies meant to replace the CGU from 2016 onwards should consider developing a new set of tailored courses for officials in line ministries and other federal bodies, aimed at helping them to respond to the specific challenges facing each public authority.

Poor implementation of FOI legislation could dissuade citizens from seeking information. In the longer term, without pressure from citizens in the form of requests for information in terms of the FOI Act, public bodies will have fewer incentives to support and invest in public transparency efforts, creating a vicious circle that will have extremely negative consequences for the broader opening up of Itamaraty and the democratisation of Brazilian foreign policy.

\section{Conclusion}

Since Brazil's return to democracy, pressures to open up Brazilian foreign policy have mounted. Among the many frontiers in this process, this article has addressed the transparency of the ministry of foreign affairs, the state agency responsible for pursuing Brazilian foreign policy, and the primary actor in the foreign policy process. Via empirical research, we have identified some of the factors detracting from the ministry's implementation of the FOI Act, not only as a gauge of transparency in Brazilian foreign policy, but also an indicator of the tensions inherent in this opening-up process. We have explained how, despite the fact that most requests for information in the period under review were granted, the denial of some pointed to the ministry's enduring resistance to engagement 
with Brazilian society. From the conflicts of interpretation over the Act's secrecy provisions and their limits in a democracy to the abusive use of denials justified by 'additional work', we have found that, in the first three years of the Act, Itamaraty did not give it the required consideration.

Besides internal resistance to complying with the Act, the ministry has also not assigned adequate material and human resources to comply with its requirements. In sum, Itamaraty has not displayed any indication that it regards implementation of the FOI Act as either necessary or urgent, as with other elements of the democratisation of Brazilian foreign policy in general (Lopes 2014a).

Although this was not our primary objective, we advanced some broader hypotheses to explain these shortcomings, including a failure to treat foreign policy as a public policy, leading to inadequate oversight by state and non-state actors; and poor management, including but not restricted to inadequate budgets. Future studies of the ministry from an institutionalist perspective could help to firm up these hypotheses. Studies of other state agencies could also flesh out the picture of how state agencies have responded to requests for information about Brazilian foreign relations.

In the meantime, Itamaraty needs to start understanding the FOI Act as a means of improving its public management. Requests for information under the FOI Act can provide the ministry with indications of which foreign policy issues interest the public, and of gaps in its management of information, which is central to its own policy cycle.

We have also identified some concrete steps for improving the transparency of Brazilian foreign policy. Among other things, we have argued that the ministry should redact classified information, and improve its proactive transparency, inter alia by publishing the long-awaited White Paper on Foreign Policy. We have also emphasised the need to strengthen oversight by developing appropriate guidelines to the FOI Act, including how 'additional data processing' should be defined and applied. Finally, we have pointed out the need to increase the autonomy of oversight bodies such as CMRI.

Itamaraty can take numerous workable steps to improve its implementation of the FOI Act. Steps should also be taken to adjust the broader institutional framework surrounding the FOI Act, which extend far beyond the ministry. Should these two things be done, we could make progress towards a republican foreign policy in Brazil, a route of choice in recent decades, and consistent with the country's journey to democracy which began in 1988.

\section{Notes}

1 The ministry is also known as Itamaraty because it is housed in the Itamaraty Palace in the national capital of Brasília, designed by the architect Oscar Niemeyer and inaugurated in 1970. In turn, this building derives its name from the fact that the ministry was previously housed in the Itamaraty Palace in Rio de Janeiro, built in the 19th century by the Baron of Itamaraty.

2 The Federal Constitution does not assign responsibility for formulating Brazilian foreign policy to a single government institution. However, a constitutional regulation (Decree No 5, 032/2004) states that the Executive Branch should play a central role in formulating foreign policy and foreign policy decisions; the Legislative Branch should participate in ex-post (co) decision-making; and the Judicial Branch should participate on an ad hoc basis. 
3 Between 1964 and 1985, Brazil was a civil-military dictatorship. It then embarked on a transition to democracy, agreed among the main political forces and sustained by the 1979 Amnesty Law. In 1988, the country enacted a new constitution, also known as the 'Citizen Constitution' due to the broad range of freedoms and rights it promotes and protects.

4 In contrast to the understanding that the politicisation of Brazilian foreign policy involves partisanship (as in Barbosa 2014a), we follow Milani and Pinheiro's definition (2013: 30) that this involves the 'intensification of the debate of ideas, values and interests on political choices, and also et pour cause, of inter and intrabureaucratic disputes, debates between different social actors and the best way to consider their demands'.

5 During these debates, some sectors articulated the need to create a National Council on Foreign Policy (Júnior and Farias 2014; GRRI 2014b) while others believed this was unecessary, and could harm Itamaraty (Barbosa 2014a).

6 The balance between diplomacy and secrecy has been a recurring theme in global history, notably in the debate that followed the First World War over the end of secret diplomacy. In recent yeras, this issue has resurfaced globally, from public diplomacy and Wikileaks to the global wave of freedom of information laws. According to FreedomInfo.org, by December 2014 a total of 102 countries had freedom of information laws. A total of 99 countries adopted freedom of information laws from the 1980 s onwards, and 72 did so in the 2000s.

7 The GCU was abolished by Presidential Decree No 726 (effective May 2016) in the context of broader ministerial reforms. At the time of writing, it was unclear how the new Oversight, Transparency and Control Ministry would promote and oversee the FOI Act. Even though this shift does not affect our analylses of the implementation of the Act in the period of study (May 2012-May 2015), it has policy implications for the future. The new body has fewer enforcement powers, since it is not hierarchically higher than the line ministries it is meant to oversee. This should be researched further.

8 Conectas Human Rights is an international non-government organisation founded in September 2001 in São Paulo, Brazil. Its mission is to promote the realisation of human rights and the democratic rule of law in the Global South - Africa, Latin America and Asia. ARTICLE 19 is an NGO founded in 1987 in the United Kingdom. It is active in numerous countries and assists people to express themselves freely, and enjoy access information and freedom of the press. [Editor's note: one of the co-authors is associated with ARTICLE 19. The other two co-authors were associated with Conectas at the time the initial research was conducted.]

9 The official number of Conectas' requests are: 09200.000058/2012-13; 09200000325/2013-33; 09200000304/2013-18; $\quad 0920000196 / 2013-83$; $\quad 03950002031 / 2014-68$; $\quad 09200000016 / 2015-25$; 09200.000103/2015-82. ARTICLE 19's requests are: 09200000355/2014-21; 09200000354/2014-86; 09200000409/2015-39; 09200000410/2015-63; 09200000411/2015-16.

10 Requests on international cooperation denied under the need of prior consent were: 09200000316/201261; 09200000196/2013-83; $\quad 09200000216 / 2013-16 ; \quad 09200000250 / 2013-91 ; \quad 09200000248 / 2013-$ 11; 09200000034/2014-26; $09200000849 / 2013-24 ; \quad 09200000399 / 2014-51 ; \quad 09200000849 / 2013-24$; 09200000272/2014-31.

11 While currently restricted to the FOI Act, this discussion could feed into a more general debate about the transparency and accountability of Brazil's role in international development co-operation (Leite et al 2014; Beghin 2014).

12 See, for example, requests number: 09200000003/2012-11;09200000077/2012-40; 09200000100/201204; $\quad 09200000130 / 2012-11 ; \quad 09200000135 / 2012-35 ; \quad 08850001096 / 2012-76 ; \quad 08850001097 / 2012-$ $11 ; \quad 09200000209 / 2012-33 ; \quad 08850003753 / 2013-09 ; \quad 09200000209 / 2013-14 ; \quad 08850000869 / 2012-05$; 09200000051/2012-00; and 09200000099/2012-18.

13 The CGU was created by the FOI Act to hear appeals against decisions to deny requests for information. In terms of Articles 68 and 69 of the Regulatory Decree, it was also responsible for monitoring, promoting and determining procedures for the application of the FOI Act. At the time of writing, the Regulatory Decree had not yet been changed to accommodate the ministerial reforms that abolished the CGU. Meanwhile, according to the FOI Act and Articles 47 and 54 of the Decree, the Mixed Commission for Information Reassessment is dealing with appeals and issues surrounding the classification of information. 


\section{References}

Araújo, Natália Lima and Deisy Ventura. 2014. 'A lenta democratização do Itamaraty: o caso do acesso à informação sobre a reforma do Sistema Interamericano de Direitos Humanos.' In Emílio Peluso Neder Meyer and Marcelo Andrade Cattoni de Oliveira (eds), Justiça de Transição nos 25 anos da Constituição de 1988. Belo Horizonte: Initia Via, pp 159-190.

Artigo 19 Brasil. 2015. Monitoramento da Lei de Acesso à Informação Pública em 2014. Available at http://artigo19.org/wp-content/uploads/2015/05/Monitoramento-da-Lei-de-Acesso-\%C3\%80Informa\%C3\%A7\%C3\%A3o-P\%C3\%BAblica-em-2014.pdf [accessed on 12 February 2016]

Avritzer, Leornardo. 2002. Democracy and the Public Space in Latin America. Princeton: Princeton University Press.

Barbosa, Rubens. 2014a. 'Sumiço do Brasil e Itamaraty marginalizado'. O Estado de São Paulo, 25 March 2014.

2014b. 'A nova agenda da Fiesp'. O Estado de São Paulo, 8 July 2015.

Beghin, Nathalie. 2014. A Cooperação brasileira para o desenvolvimento internacional na área de segurança alimentar e nutricional: avanços e desafios; onde estamos e para onde vamos? Brasília: INESC.

Brazil. 2011a. Law No 12.527, from 18 November 2011.

2011b. Parceria para Governo Aberto, Primeiro Plano de Ação. Available at: http://www. governoaberto.cgu.gov.br/no-brasil/planos-de-acao-1/1o-plano-de-acao-do-brasil [accessed on 9 February 2016]

2012. Decree No 7.724, from 16 May 2012.

2013. Parceria para Governo Aberto, Segundo Plano de Ação [online]. Available at http:// www.governoaberto.cgu.gov.br/central-de-conteudo/documentos/arquivos/2-plano-acao-brasil-2013-15.pdf [accessed on 9 February 2016]

Bennett, Andrew. 2002. 'Case study methods: design, use, and comparative advantages'. In Detlef F Sprinz and Yael Wolinsky (eds), Cases, Numbers, Models: International Relations Research Method [online]. pp. 27-64. Available at: http://www.sscnet.ucla.edu/polisci/faculty/trachtenberg/ syllabi,lists/harvard/moravcsik\%20(sprinz\%20wolinsky).pdf\#page $=27$.

Casarões, Guilherme. 2014. 'Itamaraty's mission: Brazil's Ministry of External Relations, a pillar of the nation, struggles toward a "democratic" foreign policy'. Cairo Review 12: 87-99

Cervo, Amado Luiz and Antônio Carlos Lessa. 2014. 'O declínio: inserção internacional do Brasil (2011-2014)'. Revista Brasileira de Política Internacional 57(2): 133-151.

Comissão Mista de Reavaliação de Informações. 2013. DECISÃO No 0149/2013-CMRI, [online] 26 September 2013. Available at: http://www.acessoainformacao.gov.br/assuntos/recursos/recursosjulgados-a-cmri/decisoes/2013-1/149.pdf [accessed on 26 October 2015]

Conectas Direitos Humanos. 2015a. 'Pedido LAI sobre processo de fortalecimento do Sistema Interamericano' [online]. Available at: <http://www.conectas.org/pt/acoes/justica/lei-de-acessoa-informacao/30-pedido-lai-sobre-processo-de-fortalecimento-do-sistema-interamericano $>$ [accessed on 5 October 2015]

2015b. 'Pedido LAI sobre telegramas que orientaram voto do Brasil na ONU sobre Irã na ONU'. [online] Available at: http://www.conectas.org/pt/acoes/justica/lei-de-acesso-a- 
informacao/90-pedido-lai-sobre-telegramas-que-orientaram-voto-do-brasil-na-onu-sobre-ira-naonu [accessed on 5 October 2015]

2015c. 'Pedido LAI sobre Fundo IBAS'. Available at: <http://www.conectas.org/pt/acoes/ justica/lei-de-acesso-a-informacao/42-pedido-lai-sobre-fundo-ibas > [accessed on 5 October 2015] Controladoria Geral da União. 2015a. Relatório de Pedidos de Acesso à Informação e Solicitantes, Órgão(s) de referência: MRE - Ministério das Relações Exteriores, Período de consulta: 5/2012 a 7/2015. Available at: <http://www.acessoainformacao.gov.br/sistema/Relatorios/Anual/RelatorioAnualPedidos.aspx $>$ [accessed on 29 July 2015]

2015b. Controladoria-Geral da União, Ouvidoria-Geral da União, Parecer N. 2131 de 22/07/2015. Brasília. p 25.

Cornwall, Andrea. 2002. 'Making spaces, changing places: situating participation in development', IDS Working Paper 173, Brighton: Institute of Development Studies.

De Faria, Carlos Aurélio Pimenta. 2012. 'O Itamaraty e a política externa brasileira: do insulamento à busca de coordenação dos atores governamentais e de cooperação com os agentes societários'. Contexto Internacional 34 (1): 311-355.

Farias, Rogério de Souza and Haroldo Ramanzini Júnior. 2015. 'Reviewing horizontalization: the challenge of analysis in Brazilian foreign policy'. Revista Brasileira de Política Internacional, 58(2): 5-22.

Finnemore, Martha and Kathryn Sikkink. 1998. 'International norm dynamics and political change'. International Organization 52 (4): 887-917.

França, Cássio and Michelle Ratton Sanchez. 2009. 'A horizontalização da política externa brasileira'. Valor Econômico, 24 April 2009, Opinião, p A14.

Gaventa, John 2006. 'Finding the spaces for change: a power analysis'. IDS Bulletin, 37: 23-33.

Grupo de Reflexão em Relações Internacionais. 2014a. 'Carta entregue ao ex-chanceler Antonio Patriota, durante a Conferência, pelo Grupo de Reflexões em Relações Internacionais'. In Gilberto Maringoni, Giorgio Romano Schutte and Gonzalo Berron (eds), 2003-2013 Uma Nova Política Externa. Tubarão: Ed Copiart.

2014b. 'A criação do Conselho Nacional de Política Externa fortalece o Itamaraty e consolida a inserção soberana do Brasil no Mundo'. Carta Capital. Available at: <http://www.cartacapital.com.br/blogs/blog-do-grri/conselho-nacional-de-politica-externa-fortalece-o-itamaraty-8986. html> [accessed on 10 September 2015].

Herdy, Thiago. 2014. 'Governo mantém segredo sobre recursos do fundo de pobreza'. O Globo [online]. 30/03/2014. Available at: <http://oglobo.globo.com/brasil/governo-mantem-segredo-sobrerecursos-do-fundo-de-pobreza-12037651> [accessed on 3 October 2015].

Hirst, Monica and Leticia Pinheiro. 1995. 'A Política Externa Brasileira Em Dois Tempos'. Revista Brasileira de Política Internacional 38 (1): 5-23. Brasília.

Inter-American Commission on Human Rights. 2007. Special Study on the Right of Access to Information. Special Rapporteur for Freedom of Expression: Washington.

2012. The Inter-American Legal Framework Regarding the Right to Access to Information. Second Edition. Washington.

Leite, Iara Costa, Bianca Suyama, Laura Trajber Waisbich and Melissa Pomeroy, with Jennifer Constantine, Lizbeth Navas-Alemán, Alex Shankland and Musab Younis. 2014. Brazil's engagement in 
international development cooperation: the state of the debate. Brighton (UK): Institute of Development Studies/Articulação SUL/CEBRAP.

Lima, Maria Regina Soares de. 2000. 'Instituições democráticas e política exterior'. Contexto Internacional 22(2): 265-303.

2003. 'O Legislativo e a Política Externa'. In Aldo Rebelo, Luis Fernades and Carlos Henrique Cardim (eds), Política Externa do Brasil para o Século XXI. Brasília: Câmara dos Deputados, Coordenação de Publicações, Série Ação Parlamentar: 41-52. Available at: < http://funag.gov.br/ loja/download/176-PolItica_Externa_do_Brasil_para_Seculo_XXI.pdf> [accessed on 10 September 2015]

Lima, Maria Regina Soares de and Fabiano Santos. 2001. 'O congresso e a política de comércio exterior'. Lua Nova: Revista de Cultura e Política 52: 121-149.

Lopes, Dawisson Belém. 2012. 'Política externa democrática: oxímoro, quimera ou tendência?' Revista Brasileira de Ciências Sociais [online]. 27 (80): 185-202

2014a. 'Da razão de estado ao republicanismo mitigado: uma narrativa Faoriana sobre a produção da Política Externa Brasileira’. Dados 57(2): 481-516.

2014b. 'Os últimos parnasianos. Ascensão e declínio do formalismo na Casa de Rio Branco’. Insight Inteligência 65: 66-76.

Lopes, Dawisson Belém and Carlos Antonio Pimenta De Faria. 2014. 'Eleições presidenciais e política externa brasileira. estudos internacionais 2(2): 139-148.

Mello, Patricia Campos. 2015. 'Itamaraty diz não ter como cobrir despesas'. Folha de São Paulo [online], 23 de janeiro de 2015. Available at: <http://www1.folha.uol.com.br/mundo/2015/01/1579222-itamaraty-diz-nao-ter-como-cobrir-despesas.shtml $>$ [accessed on 5 October 2015]

Mendel, Toby. 2009. Liberdade de Expressão: um estudo de direito comparado. Second edition. UNESCO. Available at: <http://portal.UNESCO.org/ci/en/files/26159/126398551119freedom_information_pt.pdf/freed om_information_pt.pdf> [accessed on 6 October 2015]

Milani, Carlos. 2011. 'Atores e agendas no campo da Política Externa Brasileira de Direitos Humanos'. In Leticia Pinheiro and Carlos R S Milani (eds), Política Externa Brasileira: as práticas da política e a política das práticas. Vol. 1. Rio de Janeiro: FGV. pp. 33-70

Milani, Carlos and Leticia Pinheiro. 2013. 'Política Externa Brasileira: Os Desafios de sua Caracterização como Política Pública. Contexto Internacional 35 (1): 11-41.

Ministério das Relações Exteriores. 2014. Discurso do Ministro Luiz Alberto Figueiredo Machado por ocasião da sessão de abertura dos "Diálogos sobre Política Externa" - Brasília, 26 de fevereiro de 2014. Available at: <http://www.itamaraty.gov.br/index.php?option=com_content\&view=article\&i $\mathrm{d}=2389$ :discurso-proferido-pelo-ministro-de-estado-das-relacoes-exteriores-luiz-alberto-figueiredo-machado-na-sessao-de-abertura-dos-dialogos-sobre-politica-externa-palacio-itamaraty-26-defevereiro-de-2014\&catid=194\&Itemid=454\&lang=pt-BR $>$ [accessed on 10 September 2015]

Nader, Lucia and Laura Waisbich. 2014. 'The long march towards the democratization of Brazilian foreign policy'. In Thijs van Lindert and Lars van Troost (eds), Shifting Power and Human Rights Diplomacy Brazil, Amnesty International, The Netherlands, pp. 87-95.

Pinheiro, Leticia. 2003. 'Os véus da transparência: política externa e democracia no Brasil'. In Aldo Rebelo, Luis Fernades and Carlos Henrique Cardim (eds), Política Externa do Brasil para o Século XXI. Brasília: Câmara dos Deputados, Coordenação de Publicações, Série Ação Parlamentar. pp. 
53-73. Available at: <http://funag.gov.br/loja/download/176-PolItica_Externa_do_Brasil_para_Seculo_XXI.pdf> [accessed on 10 September 2015]

Pinheiro, Letícia and Carlos Milani (eds). 2011. Política Externa Brasileira: as práticas da política e a política das práticas. Rio de Janeiro: FGV.

Ramanzini Júnior, Haroldo and Rogério de Souza Farias. 2014. 'Participação Social e Política Externa'. Mundorama [online]. Available at: <http://mundorama.net/2014/09/10/participacao-social-epolitica-externa-por-haroldo-ramanzini-junior-rogerio-de-souza-farias/\#more-14526> [accessed on 29 September 2015]

Ramos, Alberto Guerreiro. 1966. Administração e estratégia do desenvolvimento: elementos de uma sociologia especial da administração. Rio de Janeiro: FGV.

Sanchez, Michelle Ratton et al. 2006. 'Política Externa como Política Pública: uma análise pela regulamentação constitucional brasileira (1967-1988)'. Revista de Sociologia Política 27: 125-143.

Spektor, Matias. 2012. 'Política externa da nova classe'. Folha de São Paulo, 5 March 2012.

Tribunal Superior Eleitoral. 2013. Seminário: presidente do TSE diz que Lei de Acesso à Informação teve influência da Corte Interamericana. Available at: <http://www.tse.jus.br/imprensa/noticiastse/2013/Novembro/seminario-presidente-do-tse-diz-que-lei-de-acesso-a-informacao-teve-influencia-da-corte-interamericana> [accessed on 9 September 2015].

\section{About the authors}

Laura Trajber Waisbich holds a master's degree in political science from the Institut d'Études Politiques de Paris (France). She is a researcher at the Brazilian Centre for Analysis and Planning (Cebrap), working on citizen participation and South-South development co-operation. She also collaborates with the South-South Cooperation Research and Policy Centre (Articulação SUL) on a range of research and impact evaluation projects. From 2011 to 2016, she worked as programme officer for Conectas Direitos Humanos in Brazil, conducting research and policy work on transparency, accountability, and citizen participation in foreign policy-making. While at Conectas she also worked as editorial assistant for Sur - International Journal on Human Rights.

Raísa Cetra holds a bachelor's degree in international relations from the Universidade de São Paulo (Brazil), and a postgraduate degree in human rights, migration and asylum from the Universidad Nacional de Lanús (Argentina). She is currently working towards a master's degree in public policy and human rights at the same university. She has research and work experience on international human rights systems, notably on the right to protest, the right to access information, the right to humane treatment, and the right to migrate. Prior to joining the Centro de Estudios Legales y Sociales (CELS - Argentina) she worked for Brazilian civil society organisations, notably Conectas Direitos Humanos, and gained experience at the Inter-American Commission on Human Rights (CIDH).

Joara Marchezini is an access to information officer at ARTICLE 19 BRAZIL. In 2012, she concluded a NOHA European master's degree in international humanitarian action at the University of Deusto in Bilbao, Spain. She also holds a postgraduate degree in human 
rights and democracy from the Coimbra University in Portugal, and a bachelor's degree in international relations from São Paulo State University. While at São Paulo, she received a scholarship from FAPESP to research the international protection of human rights in armed conflicts. Recently, she worked as an independent consultant for the Brazilian Federal Human Rights Secretariat. She has also worked for Fundación Save the Children and Amnistia Internacional Portugal.

Received on 15 February 2016, and approved for publication on 13 July 2016. 